\title{
Healthy Living: Reliable Web Sites ${ }^{1}$
}

Linda B. Bobroff and Leigh Ann Martin ${ }^{2}$

Did you know that the Internet now has over 185 million Web sites? It may be hard to imagine, but it's true, and the number of Web sites is growing every day. Unfortunately, there are no regulations to ensure that the information you find on Web sites is accurate. In fact, there are many Web sites that do NOT provide reliable information.

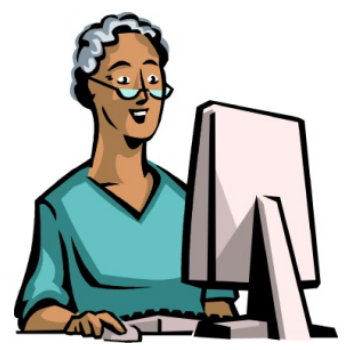

\section{So how can you choose Web sites wisely?}

Focus on government and education sites-look for Web site addresses (URLs) that end in .gov or .edu. Many organizations (.org sites) also provide sound information. Be aware that commercial (.com) sites may promote products or services, and their information may or may not be reliable or unbiased.

Here is a list of a few trustworthy Internet sources related to nutrition, health, food safety, and resources for older persons. Many of them provide links to additional Web sites.

\section{Nutrition and Health}

National Agricultural Library/U.S. Department of Agriculture

http://www.nutrition.gov

(Nutrition and health resources, including food assistance; link to government

nutrition and health Web sites)

National Library of Medicine:

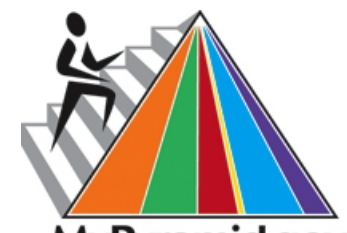

MyPyramid.gov

STEPS TO A HEALTHIER YOU

http://medlineplus.gov

(Health, drugs, supplements, medical terms, provider directories; information in over 40 languages)

U.S. Department of Agriculture:

http://www.cnpp.usda.gov/

(Nutrition education for adults and children/youth, including MyPyramid, Dietary Guidelines, nutrient content of foods, and more)

1. La versión en español de este documento es Vida Saludable: Sitios Web Confiables (FCS8587span). This document is FCS8587, one of a series of the Department of Family, Youth and Community Sciences, Florida Cooperative Extension Service, Institute of Food and Agricultural Sciences, University of Florida. First published: March 2000. Revised: July 2009.

2. Linda B. Bobroff, PhD, RD, LD/N, professor and Leigh Ann Martin, former ENAFS Project Coordinator, Department of Family, Youth and Community Sciences; Institute of Food and Agricultural Sciences; University of Florida; Gainesville, FL 32611. 


\section{Food Safety}

National Food Safety Database:

http://foodsafety.ifas.ufl.edu/indexNFSDB.htm

(Consumer, food industry and educator resources)

U.S. Government:

http://www.foodsafety.gov

(Food Safety news, advice, regulations, gateway to government food safety information)

U.S. Food and Drug Administration: http://www.fda.gov/Food/FoodSafety

(Food safety materials in English and Spanish)

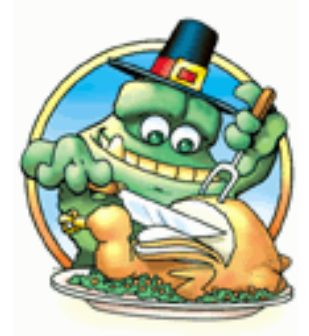

Fight BAC: Keep Bacteria out of your refrigerator!

\section{Disease Management and Reducing Risk}

National Diabetes Education Program:

http://ndep.nih.gov

(Prevention, treatment and research; materials in English and Spanish)

\section{기는 National Diabetes NDEP Education Program}

National Heart, Lung and Blood Institute:

http://www.nhlbi.nih.gov

(High blood pressure, cholesterol, sleep concerns, healthy recipes and more)

The National Osteoporosis Foundation:

http://www.nof.org

(Prevention, treatment and research)

\section{General Interest for Older Adults}

National Institute on Aging:

http://www.nih.gov/nia

(Publications related to care giving, healthy aging, medications, and more; in English and Spanish)

FirstGov for Seniors:

http://www.firstgov.gov/Topics/Seniors.shtml

(Resources, laws and regulations, consumer information, and more; English and Spanish)

Administration on Aging:

http://www.aoa.gov

(Statistics, programs, benefits, and more)

Florida Department of Elder Affairs:

http://elderaffairs.state.fl.us

(Information, resources, programs in Florida; English and Spanish)

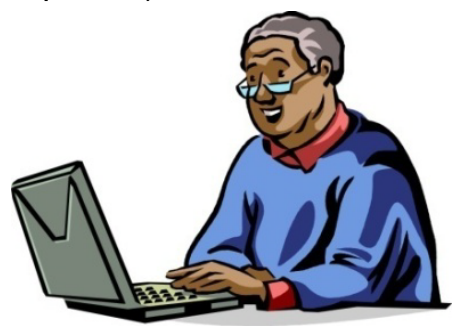

To see if programs of interest to you are being offered in your county, call your county Extension office. Check the blue pages of your telephone book for the number. In Florida, you can find your local Extension office online: http://solutionsforyourlife.ufl.edu/map/index.html. 